\title{
Innovation activities of Czech businesses: differences between urban and rural businesses
}

\author{
Iveta Kmecová $^{1 *}$, Marek Vokoun ${ }^{1}$ \\ ${ }^{1}$ The Institute of Technology and Business in České Budějovice, Faculty of Corporate Strategy, \\ Okružní 517/10, 37001 České Budějovice, Czech Republic
}

\begin{abstract}
Innovative activities of small and medium-size enterprises (SMEs) in rural areas and in Czech economy are relatively unexplored areas. Socioeconomic and environmental contributions of SMEs activities can be gained not only by means of ecological innovative activities of rural SMEs. Rural areas are also a suitable localization strategy for obtaining public money from subsidies, as there is no great direct competition and lower costs. SMEs economic contributions are irreplaceable both for urban and rural areas. Socioeconomic impact of ecological innovations for urban and rural areas is connected with the advantages of circular economy, such as reduced energy consumption, less pollution and waste, and wellorganized product recycling options after use. The hypotheses are focused on the localization of businesses into rural areas, size of enterprises introducing innovations in the market, and ecological product and processes innovations. Estimation is based on 4 innovation phases as in the case of the general innovation business process. The 2014 data set is provided by the Czech Statistical Office contains the Community Innovation Survey. The results for 2014 indicate that localization does not affect the first phases of the innovation process, and that the innovative activities increase the costs of the R\&D activities.
\end{abstract}

Keywords: Rural areas, sustainable innovation, innovative approach, socioeconomic development

\section{Introduction}

Small and medium-size enterprises (SMEs) in rural areas are more likely to use Open Innovation Framework for obtaining and application of technologies. Internal research and development activities focused on creating new products are traditionally associated with large enterprises [1]. Rural area is more often the domain of small and medium-size enterprises, which cooperate on innovations to a large extent, enter open innovation projects, and acquire and purchase predominantly external knowledge and technologies.

The research which includes innovative activities of small and medium-size enterprises is quite extensive and shows ambiguous results in the area of rural development and innovative activities. The results indicate that the historical and cultural context of the rural development and national innovation policy [2].

\footnotetext{
*Corresponding author: kmecova@mail.vstecb.cz
} 
There are many theoretical frameworks for SMEs development, where the new strategies are created according to large manufacturing enterprises (see [3, p. 899]. The product portfolio of SMEs is usually not as large as that of large companies; SMEs also tend to fail in strategic planning, although they are more innovation-intensive compared to large enterprises [4].

The consequences of failing strategies are more likely to appear for SMEs in urban areas than for those in urban areas, since there are more manufacturing companies that kind of "mirror" each other. Sustainability ideas and strategies can help enterprises to start and develop their own continuous innovation projects. However, there is still a problem unsolved: How to persuade strategic managers to adopt general academic sustainability frameworks and consider also ecologic issues?

Eco-innovators are considered long-term sustainable entrepreneurs since they contribute significantly to solving environmental and social problems. Business is associated with profit maximizing, where a part of it is used for the company social responsibility policies (CSR). Such a sustainable entrepreneur has own ecological and social preferences [5].

Hallstedt, Thompson and Lindahl [6] propose key elements for the perspective of strategic sustainability leading to product ecological innovation. The main element is the commitment of the managers. The mission of the enterprise must consider sustainability and environmental care. Another issue to take into account is the supply chain sustainability, building long-term company image as a sustainable company, etc. The final part deals with the management audit, that is, evaluation, long term plans and reverse planning. This is hard to apply in rural sector, since the research describes 6 large European manufacturing product innovators. However, the idea of joining a sustainable supply chain is applicable for rural sector and ecological innovations.

The quality of the network in the territory is crucial for stimulating innovation activities. The network of suppliers, universities, and other organizations is important for dissemination of ideas and technologies of sustainability [7, 8]. However, there can be a problem with the fact that the networks are to large extent a product of market mechanism where competition is monitored, and the business strategies depend on costs and benefits. If the sustainability ideas are too costly for the members of the network, they will not be disseminated. Public support can be a solution that is provided either in a traditional way or by means of experimental and "fail-proof" adaptive urban design and pilot testing [9].

\section{Data and methods}

Czech innovation surveys (CSI) in the Czech Republic in 2014 contain issues concerning innovations with environmental benefits for an enterprise or final product user, and the information of the enterprise localization and its size [10]. Apart from the innovation activities discussed, effective and systematic corporate education (as part of the overall company strategy) also appears to play a certain role affecting sustainability and competitiveness in the present economy of knowledge [11, 12].

The dependent variables (Table 1) describe innovative activities of enterprises. Innovative variable represents all companies with zero research and development costs (that is, internal research and development expenditures, obtaining external knowledge, purchasing machinery, equipment, software, and facilities, trainings focused on innovation costs and costs related to introducing innovations in the market).

This paper deals with small and medium enterprises (SMEs). Size is determined only by the number of full-time employees. Urban space is determined by the 3-digit NUTS code (criterium was based on districts cities with less than 25,000 inhabitants). 
Table 1. Dependent variables

\begin{tabular}{|l|r|r|r|r|r|}
\hline \multicolumn{1}{|c|}{ Variable } & Obs. & Mean Value & Standard Deviation & Min & Max \\
\hline R\&D innovator (\%) & 5198 & 0.40 & 0.49 & 0 & 1 \\
\hline New-to-the-market innovator (\%) & 1761 & 0.55 & 0.49 & 0 & 1 \\
\hline R\&D per one employee (1,000 CZK) & 5198 & 65.97 & 261.22 & 0 & 7018 \\
\hline Environmental innovation (\%) & 5198 & 0.36 & 0.48 & 0 & 1 \\
\hline Rural enterprise (\%) & 5198 & 0.19 & 0.39 & 0 & 1 \\
\hline
\end{tabular}

Source: Own processing, based on CIS data.

The quality of innovation can be distinguished, but is based on self-reporting. There are three possible innovator variables. The most restrictive is the definition of a patent, which consists of observations by businesses that have applied for a patent at the European Patent Office. Innovators who have introduced a new or significantly improved product to the market before the competition are called New-to-the-market innovators. Innovators who have introduced a new or significantly improved product that is already available on the market are more like "imitators" and are adapting to the technological boundary of the industry, the so-called new-to-the-firm innovator.

Table 2. Summary statistics of eco-innovation activities

\begin{tabular}{|l|r|r|r|}
\hline \multicolumn{1}{|c|}{$\begin{array}{c}\text { Environmental benefits obtained } \\
\text { within your enterprise }\end{array}$} & $\begin{array}{c}\text { Number of } \\
\text { obs. }\end{array}$ & \multicolumn{1}{c|}{$\begin{array}{c}\text { Mean } \\
\text { Value }\end{array}$} & $\begin{array}{c}\text { Standard } \\
\text { Deviation }\end{array}$ \\
\hline $\begin{array}{l}\text { Reduced material or water use } \\
\text { per unit of output }\end{array}$ & 5198 & 0.15 & 0.36 \\
\hline $\begin{array}{l}\text { Reduced energy use or CO2 'footprint' } \\
\text { (reduce total CO2 production) }\end{array}$ & 5198 & 0.20 & 0.40 \\
\hline Reduced air, water, noise or soil pollution & 5198 & 0.15 & 0.35 \\
\hline $\begin{array}{l}\text { Replaced a share of materials } \\
\text { with less polluting or hazardous } \\
\text { substitutes }\end{array}$ & 5198 & 0.10 & 0.30 \\
\hline $\begin{array}{l}\text { Recycled waste, water, or materials } \\
\text { for own use or sale }\end{array}$ & 5198 & 0.18 & 0.39 \\
\hline $\begin{array}{l}\text { Environmental benefits obtained } \\
\text { during the consumption or use } \\
\text { of a good or service by the end user }\end{array}$ & $\begin{array}{r}\text { Number of } \\
\text { obs. }\end{array}$ & $\begin{array}{c}\text { Mean } \\
\text { Value }\end{array}$ & $\begin{array}{c}\text { Standard } \\
\text { Deviation }\end{array}$ \\
\hline Reduced energy use or CO2 'footprint' & 5198 & 0.15 & 0.35 \\
\hline Reduced air, water, noise or soil pollution & 5198 & 0.11 & 0.31 \\
\hline Facilitated recycling of product after use & 5198 & 0.10 & 0.30 \\
\hline
\end{tabular}

Source: Own processing.

Ecological innovative activities are dominated by innovations focused on the production process in the enterprise, namely Reduced energy use or $\mathrm{CO} 2$ 'footprint' (reduce total $\mathrm{CO} 2$ production), Recycled waste, water, or materials for own use or sale and Reduced material or water use per unit of output. This results in eco-friendly production, which brings benefits in the form of Reduced energy use or $\mathrm{CO} 2$ 'footprint' (Table 2) for the consumer and the environment. 
Table 3: Estimation method - based on Heckman procedure

\begin{tabular}{|l|c|}
\hline $\begin{array}{l}\text { Innovation } \\
\text { decision }\left(r_{i}^{*}\right)\end{array}$ & $\left\{\begin{array}{l}r_{i}^{*}=1 \text { if } r_{i}=\left(X_{1 i} \beta_{1}+\varepsilon_{i_{1}}\right)>0 \\
\text { if } r_{i} \leq 0\end{array}\right.$ \\
\hline $\begin{array}{l}\text { R\&D intensity } \\
\text { variable }\left(k_{i}^{*}\right)\end{array}$ & $k_{i}^{*}=\ln \left(k_{i}^{*}\right) \|\left(r_{i}>0\right)=X_{2 i} \beta_{2}+\varepsilon_{i_{2}}$ \\
\hline
\end{tabular}

Source: Own processing.

The vector of parameters to be estimated is denoted by $\beta n$ (with $n=1$ and 2 ). In case of Probit probability, marginal effects at means are reported. The first innovation-decision equation ( $\mathrm{ri}^{*}$ ) accounts for selection into all R\&D activities, it deals with the probability of an enterprise $\mathrm{i}$ to engage in non-zero R\&D. This is specified as a Probit model, i.e. $\mathrm{P}\left(\mathrm{ri}^{*}>0\right)$ $=\Phi(\mathrm{X} 1 \mathrm{i} \beta 1)$, where $\mathrm{i}^{*}$ equals 1 if enterprise $\mathrm{i}$ has non-zero total $\mathrm{R} \& \mathrm{D}$ expenditures. Cluster robust standard errors were used. In the next equation only non-zero R\&D expenditures innovators are considered. The second linear equation ( $\left.\mathrm{ki}^{*}\right)$ describes the log of total $\mathrm{R} \& \mathrm{D}$ expenditures to the number of employees in enterprise i. This equation is uniquely dependent on market orientation and public funding variables (Table 3). In relation to that, the calculations were based on the so-called Heckamn coorection (procedure) which is possible to use when modifications of non-randomly selected units should occur.

\section{Results}

There is no evidence about different patterns of general R\&D activities between the rural and urban space at the beginning of the innovation process (table 4). The decision to innovate and innovation intensity of rural enterprises is similar to urban enterprises. In other words, there are more important variables. The decision to innovate (non-zero R\&D expenditures, no restrictions about the innovation level) is positively dependent on market orientation and size. SMEs are less likely to engage innovation projects regardless of the localization. On the other hand, they are more intensive than large companies in terms of R\&D spending per employee.

Eco-innovation activities contribute to the higher innovation intensity. Intuitively, the public funding (central government and EU), the high technological and knowledge level contribute to the higher R\&D intensity. Interestingly, prestigious Horizon 2020 programs did not contribute to the higher R\&D intensity. Cooperation increased the intensity as well as foreign ownership. 
Table 4: Innovation decision and R\&D intensity

\begin{tabular}{|c|c|c|}
\hline Varaibles & Innovator $(0,1)$ & R\&D exp. per employee (ln) \\
\hline \multirow[t]{2}{*}{ Number of employees $(\ln )$} & $0.230^{* * *}$ & $-0.362 * * *$ \\
\hline & $(0.02)$ & $(0.06)$ \\
\hline \multirow[t]{2}{*}{ Rural company ( $<25$ thousand) } & -0.045 & -0.103 \\
\hline & $(0.05)$ & $(0.10)$ \\
\hline \multirow[t]{2}{*}{ Eco-innovation activity } & & $0.365 * * *$ \\
\hline & & $(0.08)$ \\
\hline \multirow[t]{2}{*}{ Part of a group } & $0.206 * * *$ & 0.074 \\
\hline & $(0.04)$ & $(0.11)$ \\
\hline Technological level & $0.176^{* * *}$ & 0.007 \\
\hline Low-Medium & $(0.06)$ & $(0.13)$ \\
\hline Technological level & $0.432 * * *$ & 0.236 \\
\hline Medium & $(0.06)$ & $(0.15)$ \\
\hline Technological level & $0.375 * * *$ & $0.620 * * *$ \\
\hline High & $(0.11)$ & $(0.22)$ \\
\hline Knowledge level & 0.071 & $0.362 * * *$ \\
\hline High & $(0.05)$ & $(0.11)$ \\
\hline \multirow{2}{*}{ Foreign ownership } & & $0.300 * * *$ \\
\hline & & $(0.10)$ \\
\hline Funding $(0 / 1)$ & & -0.036 \\
\hline Local or regional authorities & & $(0.13)$ \\
\hline Funding $(0 / 1)$ & & $0.714 * * *$ \\
\hline Central government & & $(0.09)$ \\
\hline Funding $(0 / 1)$ & & $0.718 * * *$ \\
\hline The European Union & & $(0.10)$ \\
\hline Funding $(0 / 1)$ & & 0.298 \\
\hline Horizon 2020 & & $(0.18)$ \\
\hline \multirow[t]{2}{*}{ Co-operated on innovation activities } & & $0.471 * * *$ \\
\hline & & $(0.08)$ \\
\hline Largest market & $0.447 * * *$ & \\
\hline National & $(0.05)$ & \\
\hline Largest market & $0.299 * * *$ & \\
\hline Europe & $(0.05)$ & \\
\hline Largest market & $0.402 * * *$ & \\
\hline World/Other & $(0.09)$ & \\
\hline \multirow[t]{2}{*}{ Mill's ratio (hazard) } & & -0.259 \\
\hline & & $(0.32)$ \\
\hline \multirow[t]{2}{*}{ Constant } & $-1.656^{* * *}$ & $4.355 * * *$ \\
\hline & $(0.07)$ & $(0.57)$ \\
\hline Observations & 5198 & 2130 \\
\hline Adjusted $R^{2}$ & & 0.145 \\
\hline
\end{tabular}

Source: Own processing.

\section{Conclusion}

Non-urban localization is an innovation friendly strategy. Results suggest that innovation networks are available for companies located in the rural areas. This paper explored general innovation activity in terms of non-zero R\&D expenditures as the criteria for being an innovator. Higher-level innovation activities are more likely to differ, yet this is a matter of further research. 
Additionally, it may be argued that SMEs are more active in terms of R\&D expenditures per one employee. Eco-innovation activities aiming at new products and production processes contributed to the higher R\&D intensity. The behavior and innovation activities of the SMEs in the rural space can be explored and compared to the large enterprises' activities, but this is also suggested as further research, since panel data structure would be more suitable for capturing the dynamics of both areas.

\section{Final reflection}

Small and medium-size enterprises (SMEs) represent an important element in the European economy. SMEs make up a substantial part of economy as such, and contribute significantly to overall employment. The role of SMEs in the individual regions consists in certain social dimension. Maintaining traditional and local production in the region influences its character. For these enterprises it is now increasingly more and more difficult to be competitive.

The European Commission appeals to member states to support SMEs, since they can be considered a key element of the economic growth, job opportunities, and innovations.

\section{Acknowledgements}

This article was supported by the project "Stabilization and development of SME in rural areas", reg. No. TL01000349, the TACR Éta programme.

\section{References}

1. V. van de Vrande, J.P.J. de Jong, W. Vanhaverbeke, M. de Rochemont, Open innovation in SMEs: trends, motives and management challenges. Technovation, 29(67), 423-437 (2008)

2. N. Rosenbusch, J. Brinckmann, A. Bausch, Is innovation always beneficial? A metaanalysis of the relationship between innovation and performance in SMEs. Journal of Business Venturing, 26(4), 441-457 (2011)

3. M. Terziovski, Innovation Practice and Its Performance Implications in Small and Medium Enterprises (SMEs) in the Manufacturing Sector: A Resource-Based View. Strategic Management Journal, 31(8), 892-902 (2010)

4. J.W. Brook, F. Pagnanelli, Engineering and Technology Management for Sustainable Business Development. Journal of Engineering and Technology Management, 34(C), 1-8 (2014)

5. S. Schaltegger, M. Wagner, Sustainable Entrepreneurship and Sustainability Innovation: Categories and Interactions. Business Strategy and the Environment, 20(4), 222-237 (2011)

6. S.I. Hallstedt, A.W. Thompson, P. Lindahl, Key elements for implementing a strategic sustainability perspective in the product innovation process. Journal of Cleaner Production, 51, 277-288 (2013)

7. D. Hart, K. Bell, L. Lindenfeld, S. Jain, T. Johnson, D. Ranco, B. McGill, Strengthening the role of universities in addressing sustainability challenges: the Mitchell Center for Sustainability Solutions as an institutional experiment. Ecology and Society, 20(2) (2015) 
8. W. Kanda, O. Hjelm, J. Clausen, D. Bienkowska, Roles of intermediaries in supporting eco-innovation. Journal of Cleaner Production, 205, 1006-1016 (2018)

9. J. Ahern, S. Cilliers, J. Niemelä, Handbook of Research on Sustainable Development and Economics. Landscape and Urban Planning, 125, 254-259 (2014)

10. Czech Statistical Office. Vzory Statistických Výkazů [Patterns of Statistical Statements] (2015)

11. Z. Caha, M. Ruschak, Differences in the Organization and Planning of Corporate Education in Medium-Sized and Large Companies in the Czech Republic. Vision 2020: Sustainable Economic development, Innovation Management, and Global Growth, pp. 2526-2533 (2017)

12. Z. Caha, Factors Affecting the Selection of an External Education Provider among Companies in the Czech Republic. Innovation Management and Education Excellence through Vision 2020, pp. 6009-6018 (2018). 